\title{
Вплив трематодної інвазії на вміст деяких груп ліпідів в організмі ставковика звичайного
}

\author{
Лідія Музика, Галина Киричук
}

Житомирський державний університет імені Івана Франка, Житомир, Україна

Адреса для листування: Lidiya.Muzyka@ukr.net

Отримано: 15.06.20; прийнято до друку: 28.08.20; опубліковано: 02.09.20

Резюме. Розглянуто особливості вмісту триацилгліцеролів (ТАГ), диацилгліцеролів (ДАГ), неетерифікованих жирних кислот (НЕЖК) та фосфоліпідів (ФЛ) у гемолімфі, гепатопанкреасі, мантії та нозі прісноводного черевоногого молюска Lymnaea stagnalis. Встановлено, що в досліджуваних молюсків дія трематодної інвазії викликає зменшення кількісного вмісту ТАГ в гемолімфі, гепатопанкреасі та нозі (на 30,40-43,37\%) та його збільшення на 66,02\% у мантії. Виявлено зменшення вмісту ДАГ у гепатопанкреасі та мантії (на 24,0\%) інвазованих тварин порівняно 3 неінвазованими. Стосовно НЕЖК, то зареєстровано зменшення вмісту цієї фракції на 24,75\% у гепатопанкреасі та його збільшення у мантії (на 32,51\%). Показано, що вміст ФЛ зростає в 1,22-3,79 раза в усіх досліджених органах ставковика звичайного. 3'ясовано тканинно-органну специфічність розподілу ТАГ, ДАГ, НЕЖК та ФЛ в організмі як інвазованих, так і інтактних L. stagnalis.

Ключові слова: Lymnaea stagnalis, неполярні ліпіди, фосфоліпіди, трематодна інвазія, метаболічна адаптація.

\section{Effects of a trematode infestation on the content of certain groups of lipids in the body of the great pond snail}

\section{Lidiya Muzyka, Galyna Kyrychuk}

Zhytomyr Ivan Franko State University, Zhytomyr, Ukraine

Address for correspondence: Lidiya.Muzyka@ukr.net

Abstract. The peculiarities of biochemical adaptation processes of mollusks under the influence of biological factors (trematode invasion) arouse considerable interest in the mechanisms of individual resistance and adaptive abilities of these animals on the one hand, and the need to clarify the most complex relationship between a parasite and a host on the other.

The analysis of literature sources showed the singularity, fragmentation and some ambiguity of the presented data concerning the effect of partenit trematodes on the content of some lipid groups in tissues and organs of Lymnaea stagnalis, which determined the purpose of this research.

The features of the content of triacylglycerols (TAG), diacylglycerols (DAG), non-esterified fatty acids (NEFA) and phospholipids (PL) in the hemolymph, hepatopancreas, mantle and foot of freshwater gastropods Lymnaea stagnalis are studied. It is determined that in studied mollusks the trematode infestation effect causes a decrease of TAG quantity in the hemolymph, hepatopancreas and foot $(30,40-43,37 \%$ less) and increases it to $66,02 \%$ in the mantle. The decrease of DAG in the hepatopancreas and mantle $(24,0 \%$ less) of infested animals compared to non-infested ones is found. As for NEFA, the reduction of this fraction of $24,75 \%$ in the hepatopancreas and its increase in the mantle (32,51\% more). It is shown that the content of PL increases 1,223,79 times in all studied organs of the great pond snail. The tissue and organ specifity of TAG, DAG, NEFA and PL distribution in the body of infested and intact L. stagnalis.

The highest levels of TAG of non-infested pond snails were observed in the most metabolically active organs - the hepatopancreas and the leg. As for DAG and NEFAs, these groups were found only in the hepatopancreas 
and the mantle of the studied animals, and the content of structural PL in the hepatopancreas exceeds their composition in the mantle by 3.24 times and in the leg by $36 \%(\mathrm{p}<0.05)$. The highest indicators of TAG content of infected specimen are found in the leg and the mantle of mollusks, the lowest - in the hemolymph.

The highest indicators of the content of DAG and NEFAs are recorded in the mantle, and it is possible to build the following series for the content of PhL in the body of L.stagnalis (in the direction of the indicator growth): leg $\rightarrow$ mantle $\rightarrow$ hepatopancreas.

Keywords: Lymnaea stagnalis, non-polar lipids, phospholipids, trematode infestation, metabolic adaptation.

\section{ВСТУП}

Актуальність вивчення біохімічного статусу молюсків, інвазованих трематодами та вільних від інвазії, зумовлено як зростаючим інтересом до проблеми біохімічної адаптації прісноводної малакофауни до дії трематодної інвазії, так і необхідністю 3'ясування найскладніших взаємовідносин паразита й хазяїна. Відомо, що для системи «паразит-хазяїн» характерний антагонізм, оскільки паразит використовує хазяїна як середовище проживання та джерело живлення, тим самим спричиняючи біохімічні перебудови вражених органів, що може призвести до серйозних структурних i функціональних змін цілісного організму враженої тварини [1]. У зв'язку 3 цим в організмі хазяїна розвивається відповідна компенсаторна реакція на біохімічному рівні, яка значною мірою визначається особливостями ліпідного метаболізму хазяїна, адже відомо [2], що первинною відповіддю на стресові впливи є модифікації фізико-хімічного стану клітинних мембран [3], a ліпіди, виступаючи одним із основних компонентів бішару, беруть участь у всіх найважливіших фізіолого-біохімічних процесах організму, сприяють стабілізації проникності мембран, нормальному функціонуванню вбудованих у неї білків, ферментів і рецепторів та мають важливе значення в пристосувальних реакціях тварини у відповідь на дію чинників різної природи. Окрім цього, триацилгліцероли $\epsilon$ фундаментальним енергетичним резервом в організмі молюсків та використовуються протягом довгого періоду розвитку, забезпечуючи всі процеси життєдіяльності, оскільки за певних умов вони швидко мобілізуються із жирових депо, легко перетворюються в інші сполуки та швидко включаються в процеси обміну [2].

Аналіз літературних джерел показав поодинокість, фрагментарність та деяку неоднозначність представлених даних щодо впливу партеніт трематод на вміст деяких груп ліпідів у тканинах та органах Lymnaea stagnalis, що й зумовило мету нашого дослідження.

\section{МАТЕРІАЛИ Й МЕТОДИ ДОСЛІДЖЕНЬ}

Об'єкт дослідження: молюски Lymnaea stagnalis (Línnaeus, 1758), зібрані в серпні 2016 p. в р. Гнилоп'ять (м. Бердичів, Житомирська обл.). Для аклімації до лабораторних умов тварин утримували протягом 14 діб в акваріумах 3 відстояною аерованою водопровідною водою за таких умов: $\mathrm{pH}=7,3-$ 7,$7 ; \mathrm{t}=18-20^{\circ} \mathrm{C}$ [4]. Перед дослідженням у кожного екземпляра вимірювали висоту й ширину черепашки та визначали тотальну масу тіла й масу органів (тканин) 3 точністю до 0,01г (WPS 1200). Для біохімічного аналізу в досліджуваних тварин відбирали гемолімфу, гепатопанкреас, мантію та ногу. Додатково 3 тканин гепатопанкреасу кожного молюска виготовляли тимчасові препарати на предмет виявлення в них трематодної інвазії. Визначення видової належності трематод проводили на живому матеріалі. Для дослідження відібрано L. stagnalis, заражених редіями та метацеркаріями Echinoparyphium aconiatum Dietz, 1909.

Ліпіди екстрагували сумішшю хлороформметанол у співвідношенні 2:1 за методом Фолча [5]. Неліпідні домішки видаляли відмиванням $1 \%$ розчином $\mathrm{KCl}$. Розділення ліпідів на окремі класи здійснювали методом одномірної тонкошарової хроматографії на пластинках «Sorbfil». Рухомою фазою була суміш гександиетиловий ефір-льодяна оцтова кислота у співвідношенні 70:30:1. Одержані хроматограми проявляли в камері, насиченій парами йоду. Кількість неполярних ліпідів (триацилгліцеролів (ТАГ), диацилгліцеролів (ДАГ), неетерифікованих жирних кислот (НЕЖК) визначали біхроматним методом [6] при довжині хвилі 615 нм. Вміст фосфоліпідів (ФЛ) визначали за кількістю неорганічного фосфору методом Васьковського [7]. Всього виконано 2880 біохімічних аналізів.

Одержані експериментальні дані опрацьовані методами варіаційної статистики 3 використанням t-критерію Стьюдента. Для оцінки достовірності зрушень використовували ступінь достовірності $\mathrm{p}<0,001-0,05$. 
Цифрові матеріали оброблено методом варіаційної статистики з використанням пакету прикладних програм STATISTICA 6.0. та «Excel».

\section{РЕЗУЛЬТАТИ ТА ЇХ ОБГОВОРЕННЯ}

Відомо, що вміст ліпідів та співвідношення окремих класів в організмі гідробіонтів залежить як від фізіологічного стану тварини, так і від дії на іï організм різних чинників середовища, в тому числі біотичної природи (трематодна інвазія) [8]. Паразитування партеногенетичних поколінь трематод в організмі молюсків роду Lymnaea призводить до глибоких гістопатологічних змін різних органів хазяїна та часто порушує його нормальну метаболічну активність, що спричиняє ослаблення організму молюска та втрату його лабільності, яка $є$ необхідною для адаптації до видозміненого водного середовища (це підтверджується високим рівнем смертності інвазованих особин за коливань та дивергенції параметрів навколишнього середовища від оптимальних для цього виду) [9]. Важливим механізмом протиінфекційної відповіді молюска $\epsilon$ структурні модифікації вмісту ліпідів клітинних мембран, а також зміни характеристик їх ліпідного складу, які спрямовані на повернення фізичного стану мембран до такого, який був до дії стресового чинника, та підтримання функціонування інвазованих органів [10].

Нами встановлено, що дія трематодної інвазії викликає статистично достовірні зміни вмісту загальних ліпідів в організмі L.stagnalis та супроводжується змінами кількісних показників їх окремих класів. Виявлено зменшення вмісту ТАГ в деяких органах інвазованих ставковиків: у гепатопанкреасі на $43,37 \%(\mathrm{p}<0,001)$, у нозі на $30,40 \%(\mathrm{p}<0,001)$ та на $31,26 \%(p<0,01)$ у гемолімфі порівняно 3 контролем (рис. 1).

Така динаміка, ймовірно, пов'язана $з$ дією на організм молюска трематодної інвазії та різким зниженням в iii гепатопанкреасі запасів глікогену, внаслідок використання його паразитами для власних енергетичних потреб [11]. У зв'язку з цим ТАГ використовуються
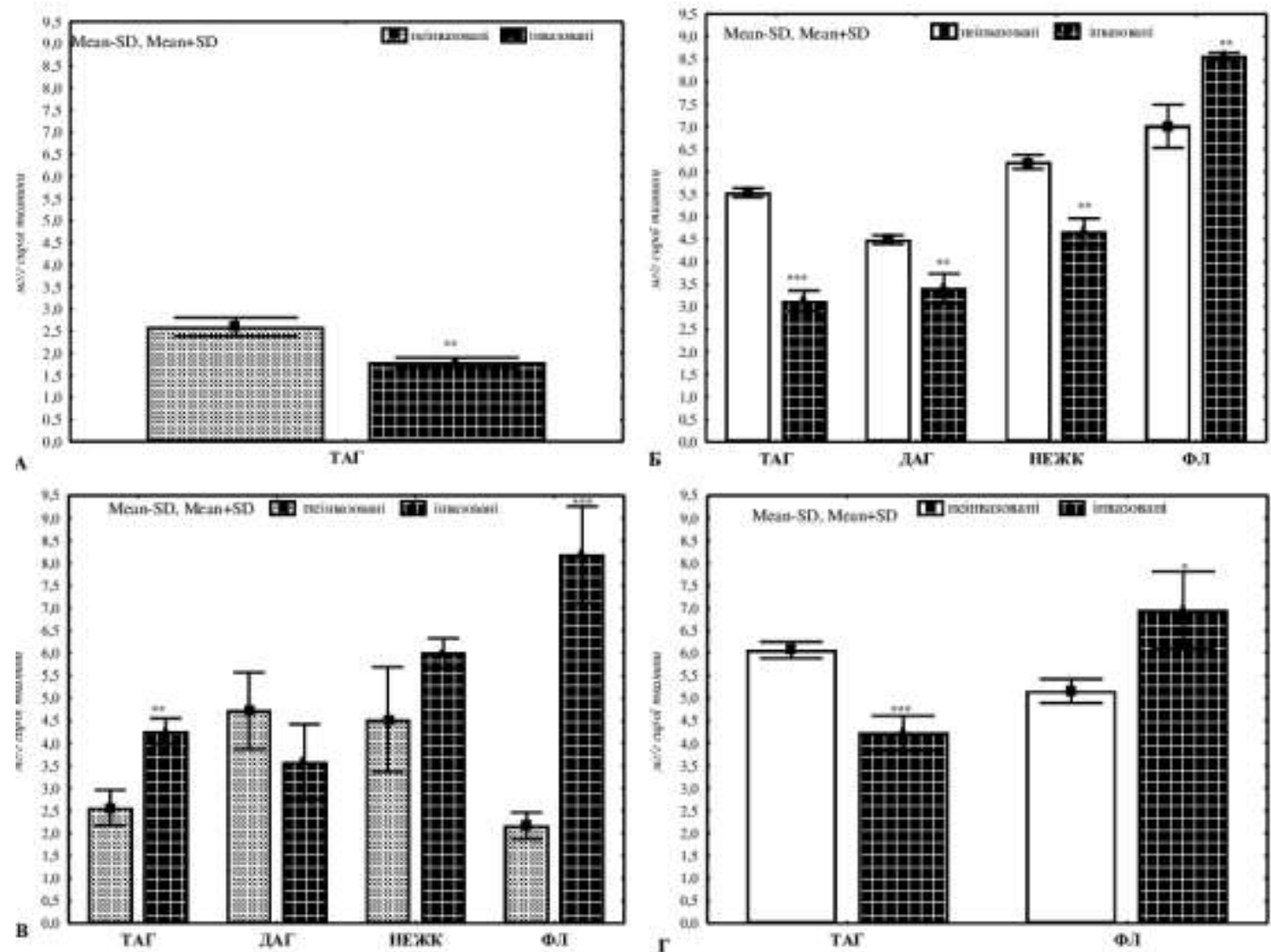

Рис. 1. Вплив трематодної інвазї̈ на вміст деяких груп ліпідів в організмі L.stagnalis ( $A$ гемолімфа; Б- гепатопанкреас; $B$-мантія; $\Gamma$ - нога)

$(*, * *, * * *$ - статистично достовірні відмінності між контрольною та дослідною групами тварин: $*-\mathrm{p}<0,05 ; * *-\mathrm{p}<0,01 ; * * *-\mathrm{p}<0,001)$ 
молюском в якості запасного джерела енергії, оскільки відомо, що триацилгліцероли в складі загальних ліпідів заповнюють дефіцит енергетичних ресурсів організму тварини та під час стресу витрачаються в першу чергу.

У зв'язку 3 вищезумовленим і відзначено зниження резерву цих ліпідів в організмі інвазованих ставковиків. Зменшення кількісних показників вмісту ТАГ також може бути спричинене значними енерговитратами молюсків у протистоянні хазяїна паразиту, а також споживанням триацилгліцеролів трематодами для власних енергетичних потреб, адже відомо, що паразити споживають суттєву частину резервів хазяїна $[12 ; 8]$.

Одночасно 3 цим зафіксовано статистично достовірне збільшення вмісту ТАГ у мантії (на $66,02 \%, p<0,01)$ L.stagnalis. Поряд із зниженням вмісту ТАГ зафіксовано зменшення й вмісту ДАГ на $24,00 \%$ у гепатопанкреасі $(\mathrm{p}<0,01)$ та мантії $(\mathrm{p}<0,05)$ інвазованих ставковиків відносно контролю.

Аналогічну тенденцію зафіксовано i для НЕЖК: відзначаємо статистично достовірне $(\mathrm{p}<0,01)$ зниження вмісту цієї фракції на $24,75 \%$ у гепатопанкреасі ставковиків, що засвідчує інгібування ліпаз і фосфоліпази, та послаблення процесів ліполізу за дії трематодної інвазії. Однак поряд із цим відзначено збільшення вмісту НЕЖК на 32,51\% у мантії L.stagnalis, що й засвідчує пригнічення синтезу ліпідів в цьому органі, адже зміни вмісту НЕЖК, як попередників синтезу ліпідів, так і продуктів їх розпаду в тканинах, є одним iз критеріїв оцінки напрямленості ліпідного метаболізму [13].

Що стосується структурних фосфоліпідів, то встановлено збільшення кількісних показників вмісту цієї фракції у всьому тілі інвазованих тварин (виняток - гемолімфа, в якій цих сполук не виявлено): від 22,12\% у гепатопанкреасі $(\mathrm{p}<0,01)$, до $34,57 \%(\mathrm{p}<0,05)$ у нозі та у 3,79 раза в мантії $(\mathrm{p}<0,001)$. Такі зміни очевидно зумовлені участю структурних ФЛ в процесі адаптації досліджуваних молюсків до дії трематодної інвазії та їх здатністю стабілізувати структурно-функціональний стан клітинних мембран за стресових впливів, адже кількісні варіації загальних фосфоліпідів підтримують та забезпечують необхідну «рідинність» клітинних мембран, необхідну для їх функціонування в змінних умовах [1]. А оскільки ферментні системи паразитів викликають розрідження мембран клітин зараженого органу, в організмі хазяїна розвивається відповідна компенсаторна реакція у вигляді модифікації ліпідного складу, спрямована на повернення фізичного стану мембрани до дії паразитарного чинника [8]. Окрім цього, встановлене нами зниження вмісту ДАГ та НЕЖК $є$ опосередкованим підтвердженням ферментативного синтезу фосфоліпідів [13]. Отримані наші результати співвідносяться 3 результатами, отриманими іншими авторами, що вказували на зміни ліпідного обміну в організмі гідробіонтів за дії паразитів та на важливу роль ФЛ у регуляції та підтриманні гомеостазу хазяїна [8; 14].

Аналіз тканинно-органного розподілу досліджуваних фракцій ліпідів показав, що в неінвазованих ставковиків найвищі показники вмісту ТАГ відзначено в метаболічно найактивніших органах - гепатопанкреасі та нозі (рис. 2А).

Так, уміст цих ліпідів в гепатопанкреасі перевищують такі в гемолімфі та мантії в 2,13 та 2,16 раза відповідно $(\mathrm{p}<0,001)$ та знаходиться в межах показників, встановлених для ноги. Що стосується ДАГ та НЕЖК, то ці групи ліпідів виявлено лише в гепатопанкреасі та мантії досліджуваних тварин, причому різниця показника ДАГ між цими органами становить лише 5,09\%, а вміст НЕЖК у гепатопанкреасі перевищує їх вміст у мантії на 37,3\% (різниця не достовірна). Вміст структурних ФЛ у гепатопанкреасі перевищує вміст їх у мантії в 3,24 раза та більший на $36 \%$ у нозі $(\mathrm{p}<0,05)$.
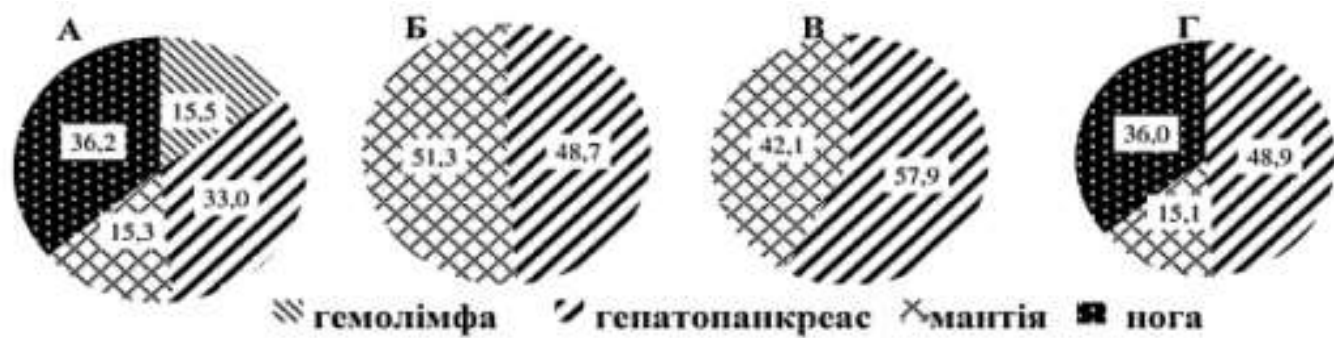

Рис. 2. Тканинно-специцфічний розподіл досліджуваних ліпідів (\%) в організмі неінвазованих L.stagnalis: $A-T A \Gamma ; Б-Д A \Gamma ; B-H Е Ж К ; \Gamma-Ф Л$ 

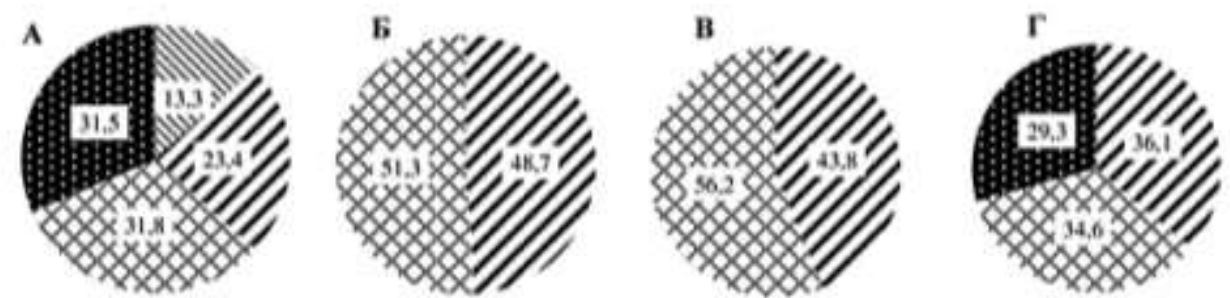

\section{N}

Рис. 3. Тканинно-специифічний розподіл досліджуваних ліпідів (\%) в організмі інвазованих

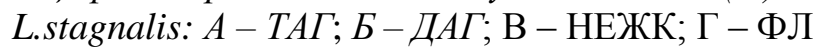

Отримані дані щодо вмісту деяких фракцій ліпідів в організмі інвазованих особин дозволяє стверджувати, що трематодна інвазія впливає на модифікації як структурних, так i енергетичних ліпідних компонентів, причому ці зміни є органно-специфічними (рис. 3).

Встановлено, що в інвазованих ставковиків найвищими показниками вмісту ТАГ характеризується нога та мантія молюсків, найнижчими - гемолімфа. Вміст ТАГ у гепатопанкреасі вищий на $75,7 \%$ від такого у гемолімфі $(\mathrm{p}<0,001)$ та на $26,47 \%$ і $25,78 \%$ менший у мантії та нозі відповідно. Такий розподіл пояснюється тим, що гепатопанкреас - один із основних органів, що виконують функцію запасання ліпідів, а також $є$ місцем їх синтезу, розщеплення та використання [10]. Саме ці метаболічні ресурси інтенсивно використовуються організмом молюсків за стресів різної природи, зокрема впливу трематодної інвазії. Найвищі показники вмісту ДАГ зафіксовано у мантії. Аналогічний ефект зафіксовано і для НЕЖК. Щодо вмісту ФЛ в організмі L.stagnalis можна вибудувати такий ряд (в напрямку зростання показника): нога $\rightarrow$ мантія $\rightarrow$ гепатопанкреас (рис. 3 Г).

\section{ВИСНОВКИ}

Встановлено, що трематодна інвазія впливає на модифікації як структурних, так i енергетичних ліпідних компонентів, причому ці зміни є органно-специфічними. Зареєстровано зменшення вмісту ТАГ, ДАГ та НЕЖК (на $24,00-43,37 \%$ ) інвазованих ставковиків порівняно 3 контролем, що пов'язано із значними енергозатратами тварин, спрямованими на протидію трематодній інвазії (за винятком мантії, у якій відзначалося збільшення вмісту ТАГ (на 66,02\%) та НЕЖК (на $32,51 \%$ ). Однак зафіксовано розвиток компенсаторної реакції L.stagnalis, скерованої на нівелювання шкідливої дії паразитів та підтримання гомеостазу інвазованої тварини у вигляді зростання показників вмісту ФЛ (в $1,22-3,79$ раза) в тканинах інвазованих тварин.

\section{ЛIТЕРАТУРА}

1. Немова, Н. Н. Механизмы биохимической адаптации у водных организмов: экологические и эволюционные аспекты. Современные проблемь физиологии и биохимии водных организмов. Том 1. Экологическая физиология и биохимия водных организмов. Сборник научных статей; КарНЦ РАН: Петрозаводск, 2010; с 198-214.

2. Фокина, Н. Н.; Нефедова, 3. А.; Немова, H. Н. Липидныцй состав мидий Mytilus edulis L. Белого моря. Влияние некоторых факторов среды обитания; Карельский научный центр РАН: Петрозаводск, 2010; 243 с.

3. Лось, Д. А. Восприятие сигналов биологическими мембранами: сенсорные белки и экспрессия генов. Соросовский образовательный журнал 2001, 7(9), с 14-22.

4. Хлебович, В. В. Акклимация животных организмов: основы теории и прикладные аспекты. Успехи совр. биол. 2017, 137 (1) с 20-28.

5. Folch, J. A.; Lees, M.; Sloante Stanley, G. H. A simple method for the isolation and purification of total lipides from animal tissues. J Biol Chem. 1957, 226(1), pp 497-509.

6. Кейтс, М. Техника липидологии. Выделение, анализ и идентификаиия липидов; Мир: Москва, $1975 ; 322 \mathrm{c}$.

7. Vaskovsky, V. E.; Kastetsky, E. V.; Vasedin, I. M. A universal reagent for phospholipids analisis. $J$. Chromatogr. 1985, 114 (1), pp 129-141.

8. McManus, D. P.; Marshall, I.; James, B.L. Lipids in digestive gland of Littorina saxatilis rudis (Maton) and in daughter sporocysts of Microphallus similis (Jäg. 1900). Exp Parasitol. 1975, 37(2), pp 157163.

9. Shakarbaev, U. A.; Mingbaev, A. S.; Akramova, F. D.; Shakarboev, E. B.; Azimov, D. A. Changes in the structure and functions of mollusc organs under the effect of Orientobilharzia turkestanica larvae. Vestnik zoologii 2013, 47(5), pp 57-61. 
10. Васильева, О. Б.; Лаврова, В. В.; Иешко, Е. П.; Немова, Н. Н. Изменение липидного состава печени налима Lota lot (L.) при инвазии плероцеркоидами Triaenophorus nodulosus. B Современные проблемы физиологии и биохимии водных организмов Том I. Экологическая физиология и биохимия водных организмов. Сборник научных статей; КарНЦ РАН: Петрозаводск, 2010. с 20-24.

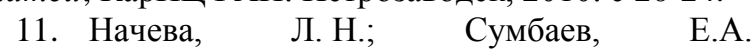
Микроморфологические изменения тканей моллюсков при развитии в них личинок трематод. Теория $u$ практика паразитарных болезней животных 2013, 14, с 263-265.
12. Ткач, П.; Высоцкая, Р. У., Керц, Е. С. Влияние гельминтной инвазии на липидный обмен бокоплавов Белого моря. Паразитология 2010, 44, 2, с 128-134.

13. Сеник, Ю. І.; Хоменчук, В. О.; Курант, В. 3.; Грубінко, В. В. Роль ліпідів еритроцитарних мембран у формуванні резистентності до йонів цинку. Біологія тварин 2013, 15 (3), с 111-119.

14. Arakelova, K. S.; Chebotareva, M. A.; Zabelinskii, S. A. Physiology and lipid metabolism of Littorina saxatilis infected with trematodes. Dis Aquat Organ. 2004, 60(3), pp 223-231. 